University of Michigan Law School University of Michigan Law School Scholarship Repository

Articles

Faculty Scholarship

2015

\title{
Mandatory Arbitration in Consumer Finance and Investor Contracts
}

Michael S. Barr

University of Michigan Law School, msbarr@umich.edu

Available at: https://repository.law.umich.edu/articles/1661

Follow this and additional works at: https://repository.law.umich.edu/articles

Part of the Banking and Finance Law Commons, Consumer Protection Law Commons, Contracts Commons, and the Dispute Resolution and Arbitration Commons

\section{Recommended Citation}

Barr, Michael S. "Mandatory Arbitration in Consumer Finance and Investor Contracts." N. Y. U. J. L. \& Bus. 11, no. 4 (2015): $793-817$.

This Article is brought to you for free and open access by the Faculty Scholarship at University of Michigan Law School Scholarship Repository. It has been accepted for inclusion in Articles by an authorized administrator of University of Michigan Law School Scholarship Repository. For more information, please contact mlaw.repository@umich.edu. 


\title{
NEW YORK UNIVERSITY \\ JOURNAL OF LAW \& BUSINESS
}

VOLUMe $11 \quad$ SPECIAL ISSUE 2015 Number 4

\section{MANDATORY ARBITRATION IN CONSUMER FINANCE AND INVESTOR CONTRACTS}

\begin{abstract}
Michael S. BARR*
Mandatory pre-dispute arbitration clauses are pervasive in consumer financial and investor contracts-for credit cards, bank accounts, auto loans, broker-dealer services, and many others. These clauses often ill serve households. Consumers are typically presented with contracts on a "take it or leave it" basis, with no ability to negotiate over terms. Arbitration provisions are often not clearly disclosed, and in any event are not salient for consumers, who do not focus on the importance of the provision in the event that a dispute over the contract later arises, and who may misforecast the likelihood of being in such a dispute. The lack of salience means that there is no meaningful competition over arbitration provisions or likely any price effect. Some arbitration proceedings lack procedural protections, and unbiased arbitrator selection essential for fair outcomes. In addition, many arbitration provisions contain "gag" rules barring disclosure of reasoning, evidence, or outcomes. Moreover, arbitration clauses typically preclude consumers from banding together in aggregated actions, which diminishes redress and weakens deterrence. In the wake of the financial crisis, Congress enacted the Dodd-Frank Wall Street Reform and Consumer Protection Act of 2010, which authorizes the new Consumer Financial Protection Bureau and the U.S. Securities and Exchange Commission to prohibit or condition the use of arbitration clauses in consumer finance and investment contracts, respectively. It is well past time for these agencies to use this authority.
\end{abstract}

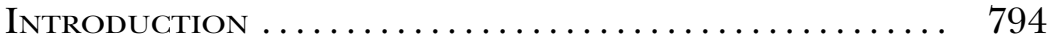

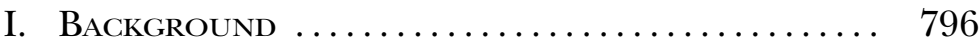

A. History ....................... 796

* Copyright (c) 2015 by Michael S. Barr. The Roy F. and Jean Humphrey Proffitt Professor of Law, University of Michigan Law School. I served as Assistant Secretary of the Treasury for Financial Institutions, and was a key architect of the Dodd-Frank Wall Street Reform and Consumer Protection Act of 2010. I would like to thank Jessica Kraft and Angela Xu for research assistance. All opinions and errors are my own. 
B. The Dodd-Frank Act's New Authority to Regulate Arbitration............................ 799

C. Arbitration Clauses in Consumer Finance and Investor Contracts Today................. 799

1. Consumer Finance Contracts............. 799

2. Broker-Dealer Agreements ............. 801

3. Investment Advisers Agreements: No

Mandatory Pre-Dispute Arbitration ......... 804

II. Problems with Arbitration Cllauses in

Investor and Consumer Finance Contracts... 805

A. Lack of Meaningful Consumer Consent ........ 806

1. Complexity of Arbitration Clauses ......... 806

2. Limited Consumer Ability to Opt-Out ...... 807

3. Behavioral Factors .................... 807

B. Imbalance of Power.................... 808

C. Procedural Barriers to Full and Fair

Adjudication......................... 809

1. Lack of Transparency................ 809

2. Selection of Arbitrators .............. 810

3. Limits on Damages ................. 811

D. Collective Redress and the Interplay Between

Public and Private Enforcement............ 812

1. The Role of Mandatory Pre-Dispute

Arbitration Clauses in Thwarting Efforts for

Collective Redress ..................... 812

2. Reduced Private Enforcement .......... 813

III. Arbitration Agreements in Other Contexts.. 814

A. Labor Agreements.................... 815

B. Commercial Actors ..................... 816

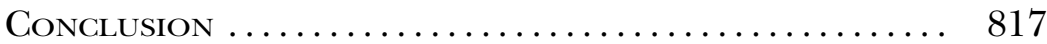

\section{INTRODUCTION}

Arbitration is widely used as an effective alternative to litigation in a variety of contexts in the United States and in many other jurisdictions. The Supreme Court has touted the benefits of arbitration over litigation, noting that "parties forgo the procedural rigor and appellate review of the courts in order to realize the benefits of private dispute resolution: lower costs, greater efficiency and speed, and the ability to choose expert 
adjudicators to resolve specialized disputes." ${ }^{\text {These benefits }}$ explain why arbitration is widely used, for example, in commercial contracts and labor-management agreements. For commercial actors, arbitration often has greater flexibility than court proceedings, and has long been considered essential for cross-border transactions. For labor unions and management, resolving disputes through arbitration "minimize[s] industrial conflict over worker grievances" and permits the business to continue to run during dispute resolution. ${ }^{2}$

In addition to agreements between sophisticated parties, arbitration clauses are now also nearly ubiquitous in American consumer contracts. Consumers are typically presented with contracts on a "take it or leave it" basis, with no meaningful ability to negotiate over terms. Arbitration provisions are often not clearly disclosed, and even when disclosed are not salient for consumers, who do not focus on the importance of the provision in the event that a dispute over the contract later arises, and who may misforecast the likelihood of being in such a dispute. As has been pointed out in a variety of contexts, non-salient contract terms that reduce consumer welfare can be offered without offsetting effects on price. ${ }^{3}$ The lack of salience at time of sale also means that there is no meaningful competition to provide contracts without arbitration provisions or with more consumer-friendly arbitration provisions. Some arbitration proceedings lack procedural protections and unbiased arbitrator selection processes essential for fair outcomes. In addition, many arbitration provisions prohibit written opinions and bar consumers from disclosing any information about the arbitration proceedings or evidence backing claims from such proceedings. Moreover, arbitration clauses today typically preclude consumers from banding together in aggregated actions. The lack of ability to aggregate claims may diminish consumer access to effective redress, particularly for

1. Stolt-Nielsen S.A. v. AnimalFeeds Int'l Corp., 559 U.S. 662, 685 (2010).

2. Linda J. Demaine \& Deborah R. Hensler, "Volunteering" to Arbitrate Through Predispute Arbitration Clauses: The Average Consumer's Experience, 67 Law \& Contemp. Probs. 55, 55 (2004).

3. See, e.g., Michael S. Barr, Sendhil Mullainathan \& Eldar Shafir, The Case for Behaviorally Informed Regulation, in New Perspectives on Regulation 25, 41 (David Moss \& John Cisternino eds., 2009). 
small-value claims, and may diminish the deterrent value of private litigation in enforcing legal norms.

This Comment focuses on the use of mandatory pre-dispute arbitration clauses in a subset of consumer contractsthose involving consumer finance and investor products and services. Arbitration clauses are pervasive in financial contracts-for credit cards, bank accounts, auto loans, brokerdealer services, and many others. In the wake of the recent financial crisis, Congress enacted the Dodd-Frank Wall Street Reform and Consumer Protection Act of $2010 .{ }^{4}$ The DoddFrank Act authorizes the new Consumer Financial Protection Bureau $(\mathrm{CFPB})^{5}$ and the U.S. Securities and Exchange Commission $(\mathrm{SEC})^{6}$ to prohibit or condition the use of arbitration clauses in consumer finance and investment contracts, respectively.

To date, neither the CFPB nor the SEC has taken regulatory action under this authority. This Comment outlines the need for increased regulation over mandatory pre-dispute arbitration clauses and suggests the need for key reforms. This Comment begins by exploring arbitration clauses in consumer finance and investor contracts, and then highlights the problems caused by mandatory pre-dispute arbitration clauses. A full treatment of potential solutions to these problems is beyond the scope of this short Comment, but will be taken up in a subsequent article.

I.

BACKGROUND

\section{A. History}

Congress enacted the Federal Arbitration Act (FAA) in 1925.7 The Supreme Court has ascribed this statute a broad purpose, perceiving it as a "congressional declaration of a liberal federal policy favoring arbitration agreements, notwith-

4. Wall Street Reform and Consumer Protection Act of 2010 (DoddFrank) § 1-1601, 12 U.S.C. $§ 55301-5641$ (2013).

5. Dodd-Frank Act $\S 1028$. The author served as Assistant Secretary of the Treasury for Financial Institutions, 2009-2010, and was responsible for developing and working with Congress to enact Dodd-Frank, including the relevant provisions discussed in this article.

6. Dodd-Frank Act $\$ 921$.

7. 9 U.S.C. $\$ 1$ (1947). 
standing any state substantive or procedural policies to the contrary." 8 The Supreme Court has not only all but foreclosed state regulation of arbitration agreements, but also has severely limited access to the courts generally for consumers seeking to challenge arbitration agreements.

The FAA provides that agreements to arbitrate "shall be valid, irrevocable, and enforceable, save upon such grounds as exist in law or in equity for the revocation of any contract." ${ }^{9}$ Under this exception to enforceability, states tried to regulate the use of arbitration clauses in consumer contracts, but the Supreme Court has interpreted this statutory carve out very narrowly, noting that the FAA was enacted "[t]o overcome judicial resistance to arbitration." 10 State courts tried to use the doctrine of unconscionability to set aside arbitration provisions that violated the state's procedural and substantive norms. The Supreme Court, however, has repeatedly upheld the validity of arbitration clauses in consumer contracts. The Court has held that the FAA of 1925 preempts a wide swath of state legislative and judicial efforts at regulation that, in the Supreme Court's view, interfered with the ability of commercial firms to use mandatory pre-dispute arbitration clauses in consumer contracts. ${ }^{11}$

The Supreme Court has interpreted the FAA broadly to uphold the enforceability of arbitration clauses. Even fraud in the formation of the contract is not grounds for evading arbitration; fraud must be found specifically in the formation of the arbitration clause itself. ${ }^{12}$ Additionally, the arbitrators, not the courts, determine the arbitrability of the underlying dis-

8. Moses H. Cone Mem'l Hosp. v. Mercury Constr. Corp., 460 U.S. 1, 24 (1983).

9. 9 U.S.C. $\$ 2$ (1947).

10. Buckeye Check Cashing, Inc. v. Cardegna, 546 U.S. 440, 443 (2006).

11. E.g., Perry v. Thomas, 482 U.S. 483 (1987).

12. Prima Paint Corp. v. Flood \& Conklin Mfg. Co., 388 U.S. 395, 402-06 (1967) (" $[\mathrm{T}]$ he federal court is instructed to order arbitration to proceed once it is satisfied that the making of the agreement for arbitration . . . is not in issue. Accordingly, if the claim is fraud in the inducement of the arbitration clause itself-an issue which goes to the making of the agreement to arbitrate-the federal court may proceed to adjudicate it. But the statutory language does not permit the federal court to consider claims of fraud in the inducement of the contract generally.") (internal quotation marks omitted); see also Buckeye Check, 546 U.S. at 445-48. 
pute. ${ }^{13}$ Even where state courts have been inclined to explore whether arbitration clauses are unconscionable, delegation clauses allow parties to delegate the decision about an arbitration clause's unconscionability to an arbitrator. ${ }^{14}$ Most controversially, perhaps, the Supreme Court has ruled that arbitration clauses can exclude class action arbitration or litigation. ${ }^{15}$

The Supreme Court has also narrowly interpreted the grounds for vacatur. Congress laid out in the FAA four circumstances under which a court can vacate an arbitral award: (1) "where the award was procured by corruption, fraud, or undue means," (2) "where there was evident partiality or corruption in the arbitrators," (3) "where the arbitrators were guilty of misconduct," and (4) "where the arbitrators exceeded their powers." 16 Even the arbitrator's misinterpretation or disregard of the law is not grounds for vacatur. ${ }^{17}$ Instead, the courts have developed the doctrine of manifest disregard of law, which requires plaintiffs to overcome a high hurdle in the form of a three-part test. ${ }^{18}$ To make matters even more difficult for plaintiffs, the parties are not allowed to supplement

13. E.g., Buckeye Check, 546 U.S. at 445-46 (noting that "as a matter of substantive federal arbitration law, an arbitration provision is severable from the remainder of the contract" and that "unless the challenge is to the arbitration clause itself, the issue of the contract's validity is considered by the arbitrator in the first instance"); see also First Options of Chicago, Inc. v. Kaplan, 514 U.S. 938, 943 (1995) (deciding that the primary power to decide arbitrability belongs to either the arbitrators or the courts as the parties agreed).

14. Rent-A-Center, W., Inc. v. Jackson, 561 U.S. 63, 71-72 (2010).

15. AT\&T Mobile LLC v. Concepcion, 131 S. Ct. 1740 (2011). For a more extensive discussion on the limitations on collective relief in arbitration, see infra Part II.D.

16. 9 U.S.C. $\$ 10$ (2002).

17. E.g., Goldman Sachs Execution \& Clearing L.P. v. Official Unsecured Creditors' Comm. of Bayou Grp., LLC, 491 F. App’x 201 (2d Cir. 2012); United Paperworkers Int'l Union v. Misco, Inc., 484 U.S. 29, 38 (1987) ("But as long as the arbitrator is even arguably construing or applying the contract and acting within the scope of his authority, that a court is convinced he committed serious error does not suffice to overturn his decision.").

18. E.g., Goldman Sachs, 491 F. App'x at 204 (applying the three-part test: (1) the court must determine whether the law that was allegedly ignored was clear, and explicitly applicable to the matter before the arbitrators; (2) the court must find that the law was improperly applied; and (3) the court must find that the arbitrator possessed the subjective intent to disregard the law). 
grounds for vacatur in the contract, ${ }^{19}$ so the arbitration clause itself cannot stipulate that mere legal error is sufficient to trigger judicial review.

\section{B. The Dodd-Frank Act's New Authority to Regulate Arbitration}

After the recent financial crisis, Congress enacted the Dodd-Frank Wall Street Reform and Consumer Protection Act of 2010. ${ }^{20}$ Bucking the trend towards greater enforcement of arbitration clauses, Congress gave the new CFPB and the SEC the respective authority to regulate and even prohibit the use of arbitration clauses in consumer finance ${ }^{21}$ and investment contracts. ${ }^{22}$ Thus, Congress has provided clear and unambiguous legislative authority to these financial regulatory agencies to regulate arbitration agreements in these contracts. To date, however, neither the CFPB nor the SEC has taken regulatory action under these broad authorities, but the CFPB has already flatly banned arbitration clauses in mortgage contracts and for whistleblowers, as required under the Act. ${ }^{23}$

\section{Arbitration Clauses in Consumer Finance and Investor Contracts Today}

\section{Consumer Finance Contracts}

The Dodd-Frank Act instructed the CFPB to "conduct a study of . . . the use of agreements providing for arbitration of any future dispute between covered persons and consumers in connection with the offering or providing of consumer financial products or services." ${ }^{24}$ In December 2013, the

19. Hall Street Associates, LLC v. Mattel, Inc., 552 U.S. 576, 578 (2008). However, parties may be able to alter the scope of judicial review in state courts. Cable Connection, Inc. v. DirecTV, 44 Cal. 4th 1334 (Cal. 2008).

20. Dodd-Frank Act $\$ \S 1-1601$.

21. Dodd-Frank Act $§ 1028$.

22. Dodd-Frank Act $\S 921$.

23. The CFPB has issued rules flatly barring mandatory pre-dispute arbitration clauses in residential mortgage loan contracts and home equity lines of credit, as required by Dodd-Frank. Dodd-Frank Act $\S 1414(\mathrm{e})$. Whistleblowers are also protected under the Dodd-Frank Act against any reduction in their rights to legal redress pursuant to mandatory arbitration provisions. Id. $\S 748$ (providing protections to whistleblowers reporting to the Commodity Futures Trading Commission); id. $§ 922$ (providing protection to whistleblowers reporting to the SEC).

24. Dodd-Frank Act $§ 1028(a)$. 
CFPB issued a preliminary report on pre-dispute arbitration clauses, ${ }^{25}$ and followed up with a second study in March 2015. ${ }^{26}$

Arbitration clauses appear in contracts representing $50.2 \%$ of outstanding credit card loans, $58.8 \%$ of checking accounts, and $83 \%$ of General Purpose Reloadable (GPR) prepaid cards. ${ }^{27}$ Currently, nearly all consumer financial contracts include no-class arbitration provisions. ${ }^{28}$ Larger financial institutions are more likely to use arbitration clauses than smaller ones. ${ }^{29}$ This holds true across all products and services the CFPB studied. To illustrate, only $7.7 \%$ of banks include arbitration clauses in checking account contracts, yet $44 \%$ of checking accounts are subject to arbitration clauses. ${ }^{30}$ Currently, $53 \%$ of credit card loans contain arbitration clauses in the agreement. ${ }^{31}$ However, this figure is artificially deflated because several large issuers settled an antitrust class action by agreeing to remove arbitration clauses for a defined period. If these issuers reinstate arbitration clauses once the period expires, then approximately $94 \%$ of outstanding credit cards will

25. CFPB, Arbitration Study Preliminary Results: Section 1028(a) Study Results to Date (2013), available at http://files.consumerfinance. gov/f/201312_cfpb_arbitration-study-preliminary-results.pdf. Industry pushback has been understandably fierce, given the stakes. Many financial institutions and law firms have vociferously criticized the CFPB's report. See, e.g., Christine A. Scheuneman et al., CFPB's Arbitration Study-A Warning to Consumer Financial Service Companies, Pillsbury (Jan. 8, 2014), http://www.pills burylaw.com/publications/cfpbs-arbitration-study-a-warning-to-consumer-financial-service-companies ("In point of fact, however, while the tone of the Study appears to be somewhat hostile to the use of arbitration clauses, an objective reading of the research indicates that the conflict resolution system that has developed is working well ... "); Michael Mallow et al., The CFPB's Unfair and Misleading Report on Arbitration, LAw360 (Jan. 24, 2014), http:// www.law360.com/articles/502651/the-cfpb-s-unfair-and-misleading-reporton-arbitration.

26. CFPB, Arbitration Study: Report to Congress, pursuant to Dodd-Frank Wall Street Reform and Consumer Protection Act $\S$ 1028(A) (2015) [hereinafter CFPB 2015 Arbitration Study], available at http:/ / files.consumerfinance.gov/f/201503_cfpb_arbitration-study-reportto-congress-2015.pdf.

27. Id. $\S 3$, at 19-28.

28. Id. $\S 1$, at 10 .

29. Id. $\$ 3$, at 19 .

30. Id. $\S 3$, at $25-26$.

31. Id. $\S 2$, at 9-10. 
be subject to arbitration clauses. ${ }^{32}$ As another example, $81 \%$ of prepaid cards, which are often used by lower-income consumers, are subject to arbitration clauses. ${ }^{33}$

\section{Broker-Dealer Agreements}

As with its recommendations on consumer finance contracts, the U.S. Department of the Treasury recommended in its 2009 financial reform proposal that the SEC prohibit or condition mandatory arbitration clauses in broker-dealer and investment adviser agreements. ${ }^{34}$ As mentioned above, the Dodd-Frank Act contains the authorization for such a prohibition or condition. ${ }^{35}$

The Financial Industry Regulatory Authority (FINRA), a self-regulatory body governing broker-dealers, is responsible for administering arbitration between broker-dealers and their clients. ${ }^{36}$ The vast bulk of disputes between broker-dealers and their clients involve arbitration, and, as with consumer arbitration clauses, the Supreme Court has repeatedly upheld mandatory pre-dispute arbitration clauses in investor-broker contracts. ${ }^{37}$ Filed claims can end with an arbitration award, or with a settlement achieved through direct negotiation or mediation. Between 21-23\% of cases were decided by arbitrators from 2011 to $2015 .{ }^{38}$ During that same time period, $51-55 \%$ of cases were settled via negotiation, and $7-10 \%$ via mediation. ${ }^{39}$

32. Id. $\S 2$, at 12 .

33. Id. $\S 3$, at 27.

34. Dep't of Treas., Financial Regulatory Reform, A New Foundation: Rebuilding Financial Supervision and Regulation, at 72 (2009), available at http://www.treasury.gov/initiatives / Documents / FinalReport_ web.pdf.

35. Dodd-Frank Act $\S 921,1028$.

36. Arbitration Process, FINRA, https://www.finra.org/ArbitrationAnd Mediation/Arbitration/Process/ (last visited Mar. 25, 2015).

37. See Shearson/American Express v. McMahon, 482 U.S. 220, 238, 242 (1987) (holding that the claims under $\$ 10(\mathrm{~b})$ of the Securities Exchange Act of 1934 and under RICO were arbitrable per the Federal Arbitration Act); Rodriguez de Quijas v. Shearson/American Express, 490 U.S. 477, 480 (1989) (holding that the claims under $\S 14$ of the Securities Act of 1933 were arbitrable).

38. Dispute Resolution Statistics, FINRA, http://www.finra.org/Arbitration AndMediation/FINRADisputeResolution/AdditionalResources/Statistics/ (last visited Mar. 25, 2015).

39. Id. 
Also during that period, the percentage of cases where the customer was awarded damages decreased from $47 \%$ to $41 \% .{ }^{40}$

There has long been some concern about the process by which FINRA selects its arbitrators. For claims of $\$ 50,000$ or less, FINRA appoints one arbitrator. ${ }^{41}$ For claims for more than $\$ 50,000$, but less than $\$ 100,000$, the parties will select and FINRA will appoint one arbitrator, unless the parties agree in writing to three arbitrators. ${ }^{42}$ For claims of more than $\$ 100,000$, the parties will select and FINRA will appoint three arbitrators. In the latter two situations, FINRA generates a random list of arbitrators from its rosters and sends that list to the parties. ${ }^{43}$ Each party strikes from the list arbitrators they do not want, and ranks the remaining choices. FINRA then combines the parties' rankings and appoints the highest ranked available arbitrator from each list to serve on the panel. Critics charge that the arbitrators on FINRA's rosters are biased or otherwise unqualified. Generally speaking, the pool of arbitrators has close ties to the financial industry, ${ }^{44}$ lacks diversity, ${ }^{45}$ and is infrequently updated. ${ }^{46}$

40. Id.

41. Arbitrator Selection, FINRA, https://www.finra.org/ArbitrationAndMe diation/Arbitration/Process/ArbitratorSelection/index.htm (last visited Nov. 15, 2014).

42. $I d$.

43. $I d$.

44. See Matthias Rieker, FINRA to Limit Use of Arbitrators with Industry Ties, Wall ST. J. (Feb. 11, 2014), http://www.wsj.com/articles/SB10001424052 702304104504579377300739589882; Mason Braswell, FINRA Approves Rule to Redefine Public Arbitrators, InvestmentNews (Feb. 13, 2014), http://www.in vestmentnews.com/article/20140213/FREE/140219936/finra-approves-rule -to-redefine-public-arbitrators; see also Peter Robison, FINRA's Arbitrators: Dubious, Asleep-Sometimes Dead, Bloomberg Businessweek (Apr. 24, 2014), http:/ / www.businessweek.com/articles/2014-04-24/finra-seeks-reform-forbroker-investor-arbitration-system ("Lawyers complain about . . . arbitrators who are reluctant to make big rulings against the industry because they won't be asked back.").

45. Mark Schoeff, Jr., PIABA Claims Arbitrator Bias-FINRA Lashes Back, INVESTMENTNEws (Oct. 7, 2014), http://www.investmentnews.com/article/ 20141007/FREE/141009934/piaba-claims-arbitrator-bias-finra-lashes-back (noting that most FINRA arbitrators are white males over sixty who hold advanced degrees, which "puts them out of touch with the average investor").

46. See Robison, supra note 44 (observing that FINRA has provided the names of dead people as potential arbitrators). 
In response to critics, and industry concern about the potential for SEC regulation, in June 2014, FINRA filed a proposed rule change with the SEC to redefine "public arbitrators." ${ }^{7}$ Parties can choose whether they want public arbitrators on their panel or not. Currently, FINRA allows people who have been out of the securities industry for at least two years to be classified as public arbitrators, as long as they have spent fewer than twenty years total in the industry. ${ }^{48}$ The proposed rule would require public arbitrators to be at least five years out of industry, and permanently disqualify professionals who worked longer than fifteen years total on behalf of industry client. ${ }^{49}$ It also classifies as non-public attorneys, accountants, and other professionals who devote more than $20 \%$ of their professional time to representing investors in securities claims. In February 2015, the SEC approved the new rule. ${ }^{50}$ FINRA and the SEC have garnered praise for this move, ${ }^{51}$ but its actual impact is not yet clear.

Recently, FINRA rejected a Schwab broker-dealer contract on the grounds that it contained a bar on class action litigation. ${ }^{52}$ FINRA reasoned that its rules have long barred such clauses, and that the FINRA Rule 2268(d), promulgated under the Securities Exchange Act of 1934, is not prohibited by the

47. Mason Braswell, FINRA Approves Rule to Redefine Public Arbitrators, INVESTMENTNEws (Feb. 13, 2014), http://www.investmentnews.com/article/ 20140213/FREE/140219936/finra-approves-rule-to-redefine-public-arbitra tors; George H. Friedman, The Camel and the Last Straw or the Frog and the Boiling Water: Pick Your Parable, Securities Arbitration Commentator (Aug. 4, 2014), http://www.sacarbitration.com/blog/camel-last-straw-frog-boilingwater-pick-parable/.

48. Mark Schoeff, Jr., FINRA Seeks to Tighten Investor Dispute Rules, INVESTMENTNEWs (June 18, 2014), http:/ / www.investmentnews.com/article/ 20140618/FREE/140619905/finra-seeks-to-tighten-investor-dispute-rules.

49. $I d$.

50. Order Approving Proposed Rule Change Relating to Revisions to the Definitions of Non-Public Arbitrator and Public Arbitrator, 80 Fed. Reg. 11695 (Mar. 4, 2015).

51. Mark Schoeff, Jr., FINRA Proposal on Public Arbitration Wins Praise, InVESTMENTNEws (Oct. 3, 2010), http://www.investmentnews.com/article/ 20101003/REG/310039991/finra-proposal-on-public-arbitration-wins-praise.

52. Decision, Dep't of Enforcement v. Charles Schwab \& Co. (Complaint 2011029760201) (FINRA Board of Governors, Apr. 24, 2014). FINRA does not permit class action arbitration, but requires broker-dealer contracts to permit class action lawsuits. 
Federal Arbitration Act. ${ }^{53}$ Some have speculated that FINRA rejected the contract in order to avoid provoking the SEC into using its Dodd-Frank Act authority to bar mandatory arbitration provisions altogether. ${ }^{54}$

\section{Investment Advisers Agreements: No Mandatory Pre-Dispute Arbitration}

Investment advisers owe a fiduciary duty to their clients. ${ }^{55}$ Accordingly, the SEC has long taken the position, even prior to the Dodd-Frank Act, that mandatory pre-dispute arbitration clauses do not constitute a waiver of rights provided under the Investment Advisers Act of 1940 (including the right to choose the forum, whether arbitration or adjudication, of dispute resolution), and that investment contracts should disclose this fact. ${ }^{56}$ However, the SEC took these positions before several Supreme Court decisions upheld arbitration clauses under the federal securities laws, and a subsequent federal district court citing those opinions upheld pre-dispute arbitration clause in an advisory client agreement. ${ }^{57}$

The SEC now has the clear power under the Dodd-Frank Act to prohibit or restrict mandatory pre-dispute arbitration clauses in these agreements going forward. ${ }^{58}$ At present, investment advisers, who deploy mandatory arbitration clauses,

53. Id.

54. Id. See Letter from Sen. Franken to the SEC, Office of Senator Franken (Apr. 30, 2013), available at http://www.franken.senate.gov/?p= press_release\&id=2381; Mark Schoeff Jr., States Urge SEC to Chuck FINRA's Schwab Decision, InvestmentNews (May 4, 2013), http://www.investment news.com/article/20130504/FREE/130509954/states-urge-sec-to-chuck-fin ras-schwab-decision; Mark Schoeff Jr. \& Mason Braswell, Seeing Writing on Wall from FINRA, Schwab Throws in Towel on Class Action Lawsuit, InVESTMENTNEws (Apr. 25, 2014), http://www.investmentnews.com/article/ 20140425/FREE/140429929/seeing-writing-on-wall-from-finra-schwabthrows-in-towel-on-class; Susan Antilla, Schwab Case Casts Spotlight on Securities Arbitration and Its Flaws, N.Y. Times (Sept. 4, 2013), http:// dealbook.nytimes.com/2013/09/04/schwab-case-casts-spotlight-on-securities-arbitration-and-its-flaws/?_r=0.

55. SEC v. Capital Gains Research Bureau, Inc., 375 U.S. 180, 191-92 (1963) (holding that $\S 206$ of the Investment Advisors Act of 1940 imposed a fiduciary duty on investment advisers).

56. SEC, Staff Study on Investment Advisers and Broker-Dealers, at 44 (2011), available at www.sec.gov/news/studies/2011/913studyfinal.pdf.

57. $I d$.

58. Dodd-Frank Act $\S 921$. 
may operate in what some see as "gray area," where they use arbitration clauses at their own risk. ${ }^{59}$ Recently, however, the SEC is reported to have pressured the Carlyle Group to remove a mandatory arbitration clause from its initial public offer filing, ${ }^{60}$ suggesting that the SEC's prior views that the fiduciary duty standard already bars use of these agreements has not changed. Moreover, the SEC is authorized under the Dodd-Frank Act to harmonize the differing standards of care for broker-dealers offering individualized investment advice, and investment advisers, by requiring that the advice be in the best interest of the investor. ${ }^{61}$ Under that approach, both broker-dealers (when providing individualized advice) and investment advisers would be prohibited from using mandatory predispute arbitration clauses.

\section{II.}

\section{Problems with Arbitration Clauses in Investor and} Consumer Finance Contracts

Proponents of arbitration often note the benefits to arbitration over litigation, stressing the faster process, reduced costs, and ability to choose expert adjudicators. ${ }^{62}$ For consumers and investors, however, the many problems with mandatory pre-dispute arbitration clauses, often significantly outweigh these benefits. Consumers and investors are not making any meaningful choice in agreeing to arbitration clauses. They face a significant imbalance of power in bargaining, if any such bargaining actually occurs. If a dispute does arise, consumers and investors often proceed without the advice of counsel and

59. Suzanne Barlyn, Do Arbitration Pacts Go Against Clients'Best Interests?, Chicago Tribune (Feb. 13, 2013), http:/ /articles.chicagotribune.com/201302-13/news/sns-rt-us-arbitration-advisersbre91c1fj-20130213_1mandatory-ar bitration-arbitration-agreements-federal-arbitration-law.

60. Carter Dougherty, Consumers May See New Limits on Mandatory Arbitration, Bloomberg Businessweek (May 21, 2012), http://www.bloomberg. $\mathrm{com} /$ news / articles / 2012-05-21/consumers-may-see-new-limits-on-manda tory-arbitration.

61. SEC, Staff Study on Investment Advisers and Broker-Dealers, at vi (2011), available at www.sec.gov/news/studies/2011/913studyfinal.pdf.

62. E.g., Stolt-Nielsen S.A. v. AnimalFeeds Int'l Corp., 130 S. Ct. 1758, 1775 (2010) (citing Gilmer v. Interstate Johnson Lane Corp., 500 U.S. 20 (1991); Mitsubishi Motors Corp. v. Soler Chrysler-Plymouth, Inc., 473 U.S. 614 (1985); Penn Plaza LLC v. Pyett, 556 U.S. 247 (2009); Alexander v. Gardner-Denver Co., 415 U.S. 36 (1974)). 
are faced with a process that is often inadequate and unfair. ${ }^{63}$ Furthermore, arbitration clauses often limit consumers' and investors' access to collective redress, which meaningfully impedes both recovery and deterrence.

\section{A. Lack of Meaningful Consumer Consent}

Even in the best of circumstances, it is hard to believe that consumers give anything like meaningful consent to arbitration clauses. ${ }^{64}$ At the moment of signing a financial contract, consumers are not focused on dispute resolution, but on the financial product or service, or more likely on the underlying thing they are trying to get done by obtaining the financial product (for example, buying a car). Even if they were focused on dispute resolution, they are unlikely to be able to forecast the circumstances under which they would find themselves in a dispute or to understand the ways in which the choice of dispute resolution might influence the outcome. These problems are compounded by the complexity of arbitration clauses, the lack of clear disclosure of the provisions (or the clear disclosure alongside many other "clear" disclosures that seem more pertinent), and the limited ability of consumers to optout of arbitration clauses. Given that consumers pay little or no attention to arbitration clauses at the time of contracting, competition does not drive firms to offer contracts without arbitration clauses or with more consumer-friendly arbitration clauses, and importantly, it is unlikely that these provisions have a significant effect on the price of consumer financial goods and services. ${ }^{65}$

\section{Complexity of Arbitration Clauses}

The CFPB analyzed the complexity of arbitration clauses in credit card contracts by measuring clause length, readabil-

63. See infra Part II.C.

64. See, e.g., Margaret Jane Radin, Boilerplate 12 (2013) (noting that consumers often do not even read boilerplate contracts and hypothesizing seven reasons for that, including: a belief that they would not even understand the terms even if they read them; a lack of awareness of being subject to those terms; and a belief that it would be unenforceable if it were harmful).

65. See Russell Korobkin, Bounded Rationality, Standard Form Contracts, and Unconscionability, 70 U. CHI. L. REv. 1203, 1253 n.189 (2003). 
ity, and grade level. ${ }^{66}$ It found that the average arbitration clause comprised $14.1 \%$ of words in the contract and consisted of $1,108.8$ words. ${ }^{67}$ The average grade level (which translates total words, total sentences, and total syllables into the level of education required to understand the text) for the arbitration clauses averaged 15.6. ${ }^{68}$ This score indicates that the text is best understood by those with some college education. In contrast, the average grade level for the remainder of the contract was 11.6, which roughly corresponds to a high school-level education. ${ }^{69}$ The meaning of delegation or anti-severability clauses, for example, likely escapes most readers. The length and complexity of arbitration clauses makes consumers less likely to understand (or even to read) them.

\section{Limited Consumer Ability to Opt-Out}

Some arbitration clauses give consumers the ability to optout of or reject the arbitration clause within a defined time period, but they appear only in a small share of agreements, ${ }^{70}$ and their exercise is typically subject to restriction. To exercise an opt-out, a consumer generally must submit a signed writing by mail within thirty or sixty days. ${ }^{71}$ If there are multiple authorized users on the account, they may each need to submit written consent for the opt-out to be effective. ${ }^{72}$ Most consumers are unlikely to exercise the opt-out options because of hassle factors and an incomplete understanding of the consequences of their decisions.

\section{Behavioral Factors}

Even if consumer contracts better disclosed mandatory pre-dispute arbitration provisions and permitted consumers to opt-out, the problem of meaningful consumer consent would remain. The use of arbitration clauses should be not measured

66. CFPB 2015 Arbitration Study, supra note 26, app. A, at 27-29.

67. Id. at 28 (To put that in perspective, that is two pages of single-spaced text in 12-point Times New Roman font.).

68. $I d$.

69. $I d$.

70. Id. at 31 (Opt-out features appear in $27.3 \%$ of credit card agreements, $26.2 \%$ of checking account agreements, and $17.6 \%$ of prepaid card agreements.).

71. $I d$.

72. $I d$. 
against some abstract notion regarding rational agents fully understanding the implications of disclosed arbitration provisions, but rather considered alongside empirical evidence regarding how actual human beings actually process information and make decisions. ${ }^{73}$ The empirical evidence is clear that consumers do not read or understand standard contract terms. ${ }^{74}$ It is highly unlikely that consumers find the relevant arbitration terms salient at the time of entering into the contract. Consumers routinely underestimate the likelihood of financial firms violating the law in a way that would affect them. ${ }^{75}$ Moreover, they are highly unlikely to understand the consequences of different choices of forum or law.

\section{B. Imbalance of Power}

A significant proportion of consumers go through the arbitration process without legal representation, whereas companies never do. From 2010 to 2012, 53\% of consumers had counsel in American Arbitration Association (AAA) arbitrations reviewed by the CFPB. ${ }^{76}$ This percentage drops to $42 \%$ in debt collection proceedings. ${ }^{77}$ In contrast, companies "almost always" retained outside or in-house counsel in both debt col-

73. Michael S. Barr, Sendhil Mullainathan \& Eldar Shafir, Behaviorally Informed Financial Services Regulation (New America Found., Asset Building Program Pol'y Paper, 2008), available at http://repository.law.umich.edu/ cgi/viewcontent.cgi?article $=1028 \&$ context=other; Michael S. Barr, Sendhil Mullainathan \& Eldar Shafir, Behaviorally Informed Home Mortgage Credit Regulation, in Borrowing to Live: Consumer and Mortgage Credit Revisited 170 (Nicholas P. Retsinas \& Eric S. Belsky eds., 2008); Barr, Mullainathan \& Shafir, The Case for Behaviorally Informed Regulation, supra note 3, at 25; Michael S. Barr, Sendhil Mullainathan \& Eldar Shafir, Behaviorally Informed Regulation, in Behavioral Foundations of Public Policy 440 (Edlar Shafir ed., 2012).

74. Yannis Bakos et al., Does Anybody Read the Fine Print? Consumer Attention to Standard Form Contracts, 43 J. Legal STUd. 1, 2-3 (2014); Florencia Marotta-Wurgler, Does Contract Disclosure Matter?, 168 J. Institutional \& Theoretical Econ. 94, 100-106 (2012).

75. See Michael S. Barr, Sendhil Mullainathan \& Eldar Shafir, Behaviorally Informed Regulation, in No Slack: The Financial Lives of Low-Income AmerICANS 246, 257-61, 267-71, 274-76 (2012); Daylian M. Cain et al., The Dirt on Coming Clean: Perverse Effects of Disclosing Conflicts of Interest, $34 \mathrm{~J}$. Legal Stud. 1, 12-14 (2005).

76. CFPB 2015 Arbitration Study, supra note 26, § 5, at 28.

77. Id. app. A, at 74 . 
lection and non-collection arbitrations. ${ }^{78}$ With lawyers representing companies, the purported benefits of an informal, lowcost proceeding are largely dissipated.

Additionally, most arbitration clauses contain carve-outs for small claims court. ${ }^{79}$ Small claims carve-outs exclude from arbitration claims that could be or had been brought in small claims court. These carve-outs are neutral in theory and have the potential to benefit consumers significantly. However, small claims court carve-outs are "significantly more likely" to be used by credit card issuers to sue consumers, rather than the other way around. ${ }^{80}$

\section{Procedural Barriers to Full and Fair Adjudication}

In addition to the problem of whether or not consumers can be considered to have actually consented to arbitration, there are procedural barriers within arbitration itself, as it is often currently conducted, that may lead to substantively unfair outcomes.

\section{Lack of Transparency}

Arbitrators are not required to issue written opinions explaining their decisions. ${ }^{81}$ This lack of transparency creates several problems for consumers. First, it prevents parties from understanding how the arbitrator arrived at his decision. ${ }^{82}$ The absence of a written record also makes it harder for the consumer to prove whether the arbitrator has displayed a manifest disregard of law when seeking judicial review. Furthermore, this opacity precludes the application of stare decisis, which in any event does not generally apply to arbitration. Since arbitrators have no body of precedent to consult, arbitra-

78. Id. app. A, at 14 .

79. Id. app. A, at 32 (finding that the incidence of small claims court carve-outs was $59 \%, 62.7 \%$, and $66.7 \%$ in contracts for checking accounts, prepaid cards, and credit cards, respectively).

80. Id. app. A, at 15 .

81. O.R. Sec., Inc. v. Prof'l Planning Assocs., 857 F.2d 742, 747 (11th Cir. 1988) (citing Wilko v. Swan, 346 U.S. 427 (1953), overruled on other grounds by Rodriguez de Quijas v. Shearson/Am. Express, Inc., 490 U.S. 477 (1989)).

82. See Lynn Katzler, Comment, Should Mandatory Written Opinions Be Required in All Securities Arbitrations?: The Practical and Legal Implications to the Securities Industry, 45 Aм. U. L. Rev. 151, 193-94 (1995). 
tion awards may suffer from unpredictability and lack of uniformity.

While arbitrators are of course free to issue written decisions, institutional factors often weigh against them doing so. Financial institutions retain control over drafting arbitration clauses, and contracts for consumer financial products and services will rarely require arbitrators to issue reasoned opinions. Moreover, the American Arbitration Association Commercial Rules and the Uniform Arbitration Act contain a presumption that a reasoned opinion shall not be issued unless the parties so require. ${ }^{83}$

Moreover, arbitration clauses often contain various forms of confidentiality or "gag" rules that prevent consumers from disclosing arbitration outcomes, or from revealing evidence used in the arbitration process, or from otherwise disparaging companies with whom they are in dispute. As a result, arbitration may result in hiding information from the public even when widespread and serious legal violations may have occurred that gave rise to the arbitration proceeding.

\section{Selection of Arbitrators}

The ability of the parties' to choose their own arbitrator is touted as an advantage because parties can theoretically choose a mutually acceptable, impartial person or panel possessing relevant expertise. Commonly, the arbitration clause stipulates an arbitration organization such as the AAA, which is currently the predominant administrator for consumer arbitration about credit cards, checking accounts, and GPR prepaid cards. ${ }^{84}$ The arbitration organization then determines the pool of prospective arbitrators, if not the actual arbitrator $(\mathrm{s}) .^{85}$ Professional arbitrators can be preferable to judges due to their subject-area expertise, and they are generally bound by codes of conduct, as are AAA arbitrators, to ensure neutrality. However, arbitrators may be biased, if they are affiliated with the industry that is the subject of the dispute. Even when arbi-

83. Abraham J. Gafni, Written Opinions in Arbitration Aren't a Given, LEGAL INTELLIGENCER (Sept. 22, 2008), http://www.adroptions.com /pdfs/08SEPTWrittenOpinions_in_ArbitrationArent_a_Given.pdf.

84. CFPB 2015 Arbitration Study, supra note 26, § 2, at 34-35.

85. Id. $\S 2$, at 40 . 
trators are truly neutral, the perception of unfairness may lead consumers to lose faith in the process.

There have been notorious examples of highly biased arbitration organizations, such as the National Arbitration Forum (NAF), that were essentially working on behalf of debt collection agencies, and offering "neutral" arbitration services that were in the interests of the debt collection firms. ${ }^{86}$ NAF has since been forced to terminate its consumer arbitration services. The current market leader in consumer arbitrations, AAA, has voluntarily agreed not to hear firm-initiated debt collection cases on the grounds that its own inquiry into such arbitrations gave it serious doubt about the fairness of the process. ${ }^{87}$

A recent study of securities arbitration found that the arbitrator's background had a significant impact on arbitration outcomes. $^{88}$ For example, industry experience tends to decrease arbitral awards for claimants. The influence of arbitrator background on outcomes is tempered, however, when claimants are represented by counsel in the arbitral proceedings. 89

\section{Limits on Damages}

Arbitration clauses can limit consumers' ability to recover damages in a number of ways. Oftentimes, arbitration clauses preclude the award of punitive damages or consequential damages, or both. ${ }^{90}$ Alternatively, they may specify strict guidelines for the arbitrator to follow in calculating the award. ${ }^{91}$ Some type of limitation on damages appears in $15 \%$ of credit card contracts with arbitration clauses and over $60 \%$ of both

86. See, e.g., State v. Nat'l Arbitration Forum, Inc., No. 27-CV-09-18550, 2009 Minn. Dist. LEXIS 340 (Minn. Dist. Ct., July 17, 2009).

87. CFPB 2015 Arbitration Study, supra note 26, app. A, at 65-66. See also Arbitration or Arbitrary: The Misuse of Mandatory Arbitration to Collect Consumer Debts: Hearing Before the Subcomm. on Domestic Policy of the H. Comm. on Oversight Eं Gov't Reform, 111th Cong. (2009) (statement of Richard W. Naimark, Senior Vice President, American Arbitration Association).

88. See Stephen J. Choi et al., The Influence of Arbitrator Background and Representation on Arbitration Outcomes, 9 VA. L. \& Bus. Rev. 43 (2014).

89. Id.

90. CFPB 2015 Arbitration Study, supra note 26, § 2, at 47.

91. Id. 
checking account and prepaid card contracts with arbitration clauses. ${ }^{92}$

\section{Collective Redress and the Interplay Between Public and Private Enforcement}

\section{The Role of Mandatory Pre-Dispute Arbitration Clauses in Thwarting Efforts for Collective Redress}

Arbitration clauses increasingly bar access to collective redress. ${ }^{93}$ Class proceedings are essential for effective redress of many small value legal claims. ${ }^{94}$ Class action arbitration, like class action litigation, solves the problem that occurs when a company's practice defrauds many people, but individual lawsuits would be impracticable because each consumer could only hope to recover a relatively minor amount. Though the amount is negligible for each individual, the error adds up to a significant windfall for the company, and the lack of collective redress diminishes the deterrent value of private litigation in shaping corporate behavior.

For those reasons, the California Supreme Court struck down waivers of class arbitration in adhesive contracts as unconscionable, in the Discover Bank rule. ${ }^{95}$ The U.S. Supreme Court, however, held in ATEST Mobility v. Concepcion that the FAA preempted the Discover Bank rule, with the result that class arbitration waivers are not permitted to be ruled unconscionable under state law, at least not under similar facts and circumstances. $^{96}$ The Court reasoned that class-wide arbitration sacrifices "the principal advantage of arbitration-its informality-and makes the process slower, more costly, and more likely to generate procedural morass than final judg-

92. Id. $\S 2$, at 47-49.

93. Id. $\S 1$, at 10 ("Nearly all the arbitration clauses studied include provisions stating that arbitration may not proceed on a class basis . . . Although these terms effectively preclude all class proceedings, in court or in arbitration, some arbitration clauses also expressly waive the consumer's ability to participate in class actions in court.").

94. See, e.g., Mace v. Van Ru Credit Corp., 109 F.3d 388, 344 (7th Cir. 1997) (noting the importance of aggregating claims in transforming "relatively paltry recoveries into something worth someone's (usually an attorney's) labor" to bring).

95. See Discover Bank v. Superior Court, 36 Cal. 4th 148, 156-58, 160 (2005).

96. AT\&T Mobile LLC v. Concepcion, 131 S. Ct. 1740, 1753 (2011). 
ment." 97 Concepcion has been widely decried for its negative impact on public access to justice. ${ }^{98}$

\section{Reduced Private Enforcement}

Class proceedings are critical components of the mix of public and private enforcement of many legal norms. Many consumer financial protection statutes contemplate that class proceedings will be conducted to enforce those norms. ${ }^{99}$ "[W]e have come to assume, quite correctly, that private actors will be the frontline enforcers in actions redressing broadscale securities fraud, consumer fraud and deceptive trade practices, . . . and many other areas." 100 Penalty levels set by statute necessarily contemplate a given mix of public and private enforcement. Thus, if consumer class relief were not available, penalty levels (and the extent of public enforcement) would need to be increased to achieve the same overall level of enforcement. ${ }^{101}$

The traditional use of private litigation to enforce individual rights in the United States has become increasingly supplemented with public enforcement. Recently, the United States "increasingly relies on states attorneys general, federal prosecutors, agencies, and legislative compensation to compensate victims on a massive scale" as reformers have moved for a focus

97. Id. at 1751 .

98. See, e.g., Frank Blechschmidt, Comment, All Alone in Arbitration: AT\&T Mobility v. Concepcion and the Substantive Impact of Class Action Waivers, 160 U. PA. L. Rev. 541, 567-70 (2012); Jean R. Sternlight, Tsunami: AT\&T Mobility LLC v. Concepcion Impedes Access to Justice, 90 OR. L. REv. 703, 720-25 (2012); Ann Marie Tracey \& Shelley McGill, Seeking a Rational Lawyer for Consumer Claims After the Supreme Court Disconnects Consumers in AT\&T Mobility LLC v. Concepcion, 45 Loy. L.A. L. Rev. 435, 466-69 (2012).

99. See, e.g., Truth in Lending Act $\$ 130,15$ U.S.C. $\$ 1640$ (2012); Equal Credit Opportunity Act $\S 706,15$ U.S.C. $\S 1691 \mathrm{e}$ (2012); Fair Debt Collection Practices Act $\S 813$, 15 U.S.C. $\$ 1692 k$ (2012); Electronic Funds Transfer Act $§ 916,15$ U.S.C. $§ 1693 m$ (2012); Credit Repair Organizations Act $\S 409,15$ USC $\S 1679 \mathrm{~g}$ (2012).

100. Myriam Gilles \& Gary Friedman, After Class: Aggregate Litigation in the Wake of AT\&T Mobility v. Concepcion, 79 U. Chi. L. REv. 623, 625-26 (2012).

101. David Noll, Assistant Professor of Law, Rutgers Univ. Sch. of Law-Newark, Contract Procedure, Regulatory Breakdown, Remarks at New York University School of Law Conference, The Future of Class Action Litigation: A View from the Consumer Class (Nov. 7, 2014) (noting that Congress controls the amount of enforcement by adjusting the incentives to litigate). 
on victims' rights. ${ }^{102}$ Although it is true that there has been an emerging trend in America towards increased public enforcement, private litigation is still an essential enforcement mechanism. ${ }^{103}$ It is, moreover, an important check on lax public enforcement. ${ }^{104}$ Notably, even many European countries, long considered to be focused on civil enforcement over private litigation, have adopted increasingly expansive collective redress procedures. In fact, there has been a "convergence" in how the United States and the European countries have attended to collective redress. ${ }^{105}$ This demonstrates that the ideal mix of public and private enforcement is fluid and can change over time. However, Congress has legislated against a backdrop of enforcement policies, and has established many privately actionable statutory schemes that depend on individuals bringing suit, individually and collectively, for enforcement. ${ }^{106}$

III.

Arbitration Agreements in Other Contexts

The use of arbitration agreements in other contexts informs the use of mandatory pre-dispute arbitration clauses in consumer contracts. Arbitration agreements in the labor context are individually negotiated between sophisticated parties, and are highly touted as beneficial for both sides. Arbitration agreements are also used by commercial actors, but, surprisingly, much less used for commercial disputes by the very same firms that impose mandatory pre-dispute arbitration agreements on consumers.

102. Adam S. Zimmerman, The Convergence of Global Settlements, PrawfsBlawg (Feb. 1, 2012), http://prawfsblawg.blogs.com/prawfs blawg/ 2012/02/the-convergence-of-global-settlements.html.

103. See Gilles \& Friedman, supra note 100, at 624-26.

104. Luigi Zingales, A Capitalism for the People: Recapturing the Lost Genius of American Prosperity (2012).

105. Zimmerman, supra note 102 (noting that “[t]he 'bottom up' approach of the United States to aggregate litigation appears to be converging with other countries' 'top-down approach." ").

106. See, e.g., Blechschmidt, supra note 98, at 567-70; Gilles \& Friedman, supra note 100, at 624-25; Sternlight, supra note 98, at 720-25; Tracey \& McGill, supra note 98, at 466-69. 


\section{A. Labor Agreements}

Collective bargaining agreements often feature mandatory arbitration provisions. Both labor unions and management are sophisticated parties who individually negotiate for these provisions. Both parties believe that dispute resolution through arbitration causes less friction than litigation. ${ }^{107}$ Additionally, both parties have more trust in arbitrators that the parties have selected themselves and tend to have more expertise in labor relations than judges with only general knowledge. ${ }^{108}$ Labor unions and management also have similar goals in maintaining a strong and competitive business, and so both stress "a conflict resolution process that would keep businesses running and avoid losses in productivity and employment."109

Unlike consumer and investor contracts, collective bargaining agreements are individually negotiated between sophisticated parties with equal bargaining power. ${ }^{110}$ As such, the specific details that are commonly found in these labor agreements can inform what should be enforced in the consumer context. One of the reasons that labor unions and management negotiate for arbitration in collective bargaining agreements in the first place is the ability to choose the arbitrator. ${ }^{111}$ One key safeguard for unionized workers is that "unions and management repeatedly arbitrate and jointly select the arbitrator."112 Joint selection helps to ensure a neutral arbitrator, ${ }^{113}$ and repeated arbitrator incentivizes the arbitrator "to perform consistently without favoring one party over the

107. Demaine \& Hensler, supra note 2, at 55.

108. See, e.g. Julius H. Cohen, The Law of Commercial Arbitration and the New York Statute, 31 YALE L.J. 147, 150 (1921) ("Presumably men of commercial experience today need no guardianship for determining, at the time of making a contract, whether they prefer the opinion of their own trade upon technical questions, or the hazardous judgment of a jury of their vicinage.”).

109. Id. See also Allison Anderson, Labor and Commercial Arbitration: The Court's Misguided Merger, 54 B.C. L. REv. 1237, 1246 (2013) (comparing the purpose of labor arbitration which is to "stabilize the workplace by preventing work stoppages" and the purpose of other arbitration which is as a replacement for litigation).

110. See, e.g., Demaine \& Hensler, supra note 2, at 55-56.

111. Id. at 55 .

112. Anderson, supra note 109 , at 1255-56.

113. Julius G. Getman, Labor Arbitration and Dispute Resolution, Paper 4403, Faculty Scholarship Series 916, 929-30 (1979). Compare this with the con- 
other." 114 Instead, labor unions and management use the outcomes to renegotiate the terms of their agreements if they want future outcomes to differ from the arbitrator's decision. ${ }^{115}$ Additional safeguards include: a duty on both parties to share information ${ }^{116}$ and a duty on the union to fairly represent its workers. ${ }^{117}$ The National Labor Relations Act requires employers to share information throughout the entire arbitration process. In labor arbitrations, arbitrators often write opinions, which allows for future arbitrators and future parties to explore patterns in prior adjudications. ${ }^{118}$

\section{B. Commercial Actors}

Notably, the same commercial actors that inflict mandatory pre-dispute arbitration agreements on their consumers do not choose to bargain for these agreements in other contracts. One study found that with large public corporations over $75 \%$ of the studied consumer agreements imposed mandatory arbitration of disputes, yet less than $10 \%$ of their "negotiated nonconsumer, non-employment contracts" included arbitration clauses. ${ }^{19}$ The authors concluded that "[t]he absence of arbitration provisions in the great majority of negotiated business contracts suggests that companies value, even prefer, litigation as the means for resolving disputes with peers." ${ }^{20}$ They further noted that " $[\mathrm{t}]$ he systematic eschewing of arbitration clauses in business-to-business contracts also casts doubts on the corporations' asserted beliefs in the superior fairness and efficiency of arbitration clauses."121 It appears, therefore, that at least some commercial actors may be using arbitration clauses against consumers for the strategic advantages it provides. Those strategic advantages are diminished, however,

sumer and investor context, in which the firm may be a repeat player in arbitration whereas the consumer may only arbitrate the one time.

114. Id. at 1556. This author also notes that the joint bargain for the particular arbitrator may justify limited judicial review of the final award.

115. Id.

116. Id.

117. $I d$.

118. Getman, supra note 113, at 920-21.

119. Theodore Eisenberg, Geoffrey P. Miller, \& Emily Sherwin, Arbitration's Summer Soldiers: An Empirical Study of Arbitration Clauses in Consumer and Nonconsumer Contracts, 41 U. Mich. J.L. REFORM 871, 876 (2008).

120. Id.

121. Id. 
when dealing with other sophisticated parties. This is shown in the revealed preferences of large companies, which choose arbitration with consumers, but prefer litigation for business-tobusiness disputes.

\section{Conclusion}

Although arbitration can provide some benefits over litigation in a variety of commercial contexts, consumers are often subject to mandatory pre-dispute arbitration clauses that diminish their legal protections, reduce recoveries, and attenuate deterrence. It can hardly be said that consumers meaningfully consent to such arrangements, and so it has often been left to courts to police these provisions through doctrines such as unconscionability. Over the years, the Supreme Court has significantly cabined the ability of courts to exercise this critical oversight role. Recently, however, Congress has stepped in through the passage of the Dodd-Frank Act to provide the authority for the CFPB and SEC to prohibit or condition the use of arbitration agreements in consumer finance and investor contracts, respectively.

The CFPB and SEC should use this new authority to prohibit or condition contractual requirements on consumers and investors to arbitrate. At a minimum, significant conditions on arbitration agreements are needed. These include both up-front protections, including prominent disclosures and easy methods to opt-out of arbitration at any time, as well as protections embedded in arbitration processes that are used in consumer finance and investor contract disputes, to ensure that they provide a fair and efficient method for resolving claims. In addition, the agencies should bar provisions in consumer finance and investor contracts that limit the ability to seek collective relief or otherwise inhibit full redress of consumer and investor claims. While this short Comment does not provide the space necessary to work out these proposals in detail, my forthcoming work will explore the parameters of these reforms. 